\title{
Girish Karnad's Hayavadana - A Setting for Sacred and Profane
}

\section{OPEN ACCESS}

Volume: 7

Issue: 4

Month: September

Year: 2019

P-ISSN: 2320-2645

Received: 22.07.2019

Accepted: 23.08.2019

Published: 01.09.2019

Citation:

Kalidasan, R., and

R. K. Jaishree Karthiga.

"Girish Karnad's

Hayavadana - A Setting

for Sacred and Profane."

Shanlax International

Journal of English, vol. 7, no. 4, 2019, pp. 57-61.

DOI:

https://doi.org/10.34293/

english.v7i4.599

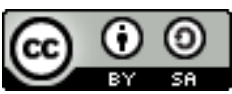

This work is licensed under a Creative Commons Attribution-

ShareAlike 4.0

International License

\section{R.Kalidasan}

Associate Professor of English (Retd.), The American College, Madurai, Tamil Nadu, India

\section{R.K.Jaishree Karthiga}

Assistant Professor, Department of English

Thiagarajar College of Engineering, Madurai, Tamil Nadu, India

\section{Abstract}

Hayavadana, a multiplex play, offers various binary themes for discussion. By combining the indigenous Yakshagana and the western Brechtian Epic theatre practices, Girish Karnad has created a unique theatre display, presenting it as a social and religious satire that point to the persistent pursuit of the humanity to achieve perfection. The plot and the sub-plot of the play get interlocked by raising questions on identity and the nature of reality. The dramatist intentionallyeffectsadynamiccommunicationbetweentheaudienceand theperformance, notingthatthe audience too are not separate from such an existential predicament. This Verfremdungseffekt or the "alienation effect", is achieved through a number of devices. One such device, apart from the folk-theatre motifs, is the philosophical survey of the concepts, 'Sacred' and the 'Profane'. This paper ventures to show how these concepts add further investigation of the play.

Keywords: multiplex play, traditional theatre, Epic theatre, alienation effect, hybridity, Sacred and Profane, transposition of heads, Goddess Kali.

Hayavadana is a multiplex work that projects binary themes such as, mind and body, desire and disappointment, completeness and incompleteness, perfection and imperfection, ancient and modern, primitive and contemporary, mythical and factual, ambiguity and certainty, trust and distrust, sacred and profane, and so on. The work is also a religious as well as a social satire, pointing to man's existential predicament and his relentless quest to achieve perfection, mocking at his simultaneous trust and distrust towards religion. By bringing together, the traditional and western theatrical conventions, he could perform this unique feat. The indigenous Yakshagana and the western Brechtian Epic theatre practices have prompted the dramatist to create a new type of dramatic performance. Arundhati Roy reviews in her article, "Transposing Realities", (The Hindu Magazine, April 14, 2002) the recent performance of the play in Kolkata. She remarks:

Girish Karnad's "Hayavadana" is one of the playwright's most-performed plays. This is hardly surprising given that the work provides the ingredients that would stimulate any innovative, intelligent troupe: a plot and sub-plot that intertwine to explore the tricky questions of identity and the nature of reality; the clever incorporation of motifs from traditional theatre - Yakshagana, a play within a play, dolls, masks; the irreverent inversion of mock-heroic mores. This is a text that begs experimentation and challenges players and audience alike to dare step "out of the box" into a whole new perception of reality. 
She thus sums up the dramatist's traditional leaning and his talent that would induce any theatredirector to invent stage-scenes and present a bizarre play. However, Ray does not fail to comment that the directors have reduced the crucial role of Hayavadana as an amusing diversion. The reviewer is a close reader of the text, must have attempted to 're-read' the book in the performance and hence feels disappointed. She says: "The power of Karnad's play is its ability to affect a dynamic process of communication between the audience and the play: through the course of the performance spectators are constantly forced to readjust their held frames of reference and find consistent patterns of meaning from seemingly incompatible stimuli". This is what Bertolt Brecht insists in his idea of "Epic Theatre", which is a form of didactic drama presenting a series of loosely connected scenes that avoid illusion and interrupt the story line to address the audience directly with analysis, argument, or documentation.

Brecht's intention was to appeal to his audience's intellect by presenting moral problems and allowing the audience to reflect on the contemporary social realities on the stage. He wishes to block their emotional responses and thwart their tendency to empathize with the characters and become caught up in action. To exercise this, he uses "alienating," or "distancing," effects to cause the audience to think objectively about the play. The Verfremdungseffekt or the "alienation effect", is achieved through several devices. The Yakshagana and some of the indigenous theatre-presentations of India, especially the folk-theatre exercise the distancing effects in their way. Karnad also opts folk-tale and myth as devices to employ the "alienation effect" and brings an insight into the issues of modern life in entirely new ways. Hayavadana is traditional yet contemporary. Vanashree Tripathi comments in her article, "Hayavadana: Towards Forging an Indian theatre":

Karnad's confabulation of the classics with the folk tales of the transposed heads and the story of a half-man, half-horse, playfully dilutes the prototypical themes, ... Where the ideal balance between duty and passion is restored. Hayavadana, in exploring the realm of love: erotic-man-woman, male bonding, parent-child, offers us insight into the desires, hopes, fulfilment and frustration it breeds. (46)

By subverting the classical themes, re-reading the myths and also by initiating the western theatrical convention, Karnad ventures to create a new mode of Indian theatre. The significant feature in Brechtian theory is that the actors must disregard inner life and emotions, but emphasize stylized external actions as signs of social relationships. The "alienation effect" thus takes the play to the philosophical enquiry of the "sacred" and the "profane" that could be seen in the dramatic structure.

The terms 'sacred' and 'profane', in general, are associated with religion, the 'sacred' referring to the divine and its attributes, and the 'profane' to the non-divine and its related aspects. The Roman, sacrum meant what related to the gods or what was in their power, and pointing to the cult ritual and its location, or with the temple and the rites given in and around it. Profanum was what was "in front of the temple precinct"; the term was always applied solely to places. Sacer and profanes were, therefore linked to specific locations. A spot or saucer was either walled off or a sanctum within the surrounding space accessible for profane use. This essentially spatial connotation adheres to the two terms to this day. This fundamental idea has specific heuristic value since it is a paradigm for making distinctions in general. Sacer-profanes duo can be well-applied to study Hayavadana, to arrive at specific interpretations. The Stage, the performing spot, becomes the sacer or sanctum. At the beginning of the performance, a mask of Lord Ganesha, the Hindu god with the elephant's head and a boy's body, is brought onstage and placed onto a chair in front of the audience. It is made sacred by conducting a puja. Thus, the sacrality of space is walled off, indicating that other actions would happen beyond this region, that is in the profanes. By commencing the play with an actual religious ritual, the puja, Karnad establishes that there will be different "layers" to the sport, not just a single, fictional plotline, and will be unique in its presentation. Following the Yakshagana convention, the Bhagavatha enters and introduces the central theme of the play, hybridity. Ganesha is the first of many hybrid beings, with a mismatched head and body to appear in the play, and interestingly occupies 
the space of the Stage, pointing to the irrefutable fact that the sacred and the profane are intertwined. The Bhagavata prays to Lord Ganesha, who is the "destroyer of obstacles," to bless the performance and make it a success. He comments that Ganesha may seem to be an imperfect being because of his hybrid state, but that his completeness is simply unknowable to mortal beings. He then introduces the two main characters, the cerebral Devadatta and the athletic Kapila. His descriptions of these friends with "one mind, one heart", exclusively centre on the intellect and muscular strength respectively. Thus, it is to be understood that from the very outset, the characters are symbolic of "the head", associated with the intellect and logic, and of "the body" associated with emotion and sexuality.

At this point, an actor runs into the stage screaming and tells the Bhagavatha that he saw a talking horse before him, as he was trying to attend his nature's call on the roadside. This comic interruption facilitates the audience with two essential facts, that of introducing the sub-plot of the play with its main character, the horse-headed man, another hybrid creature, and of demonstrating that the profane is spread out in a limitless space, comprising many human activities, and is quite close to the sacred. Brechtian "alienation effect" is resourcefully employed here, as Karnad uses the technique of the mobile-curtain of the Yakshagana theatre and makes Hayavadana hide behind it. When the stage-hands lower the curtain, Hayavadana is shown in his full hybrid form -- half-horse, halfman. This is an excellent example of Karnad using the regional theatrical tradition by giving a modern update, which also symbolizes man's schizophrenic terror that reduces him incomplete and imperfect. With Hayavadana's entry, the use of masks in the play is inducted. The masks not only signify the hybrid creatures but also draw the attention of the audience to the theatre-artifice. They have a more important part to play, that of highlighting the storyline of the transposed heads of the friends with "one mind, one heart", the confusion and conflict brought in because of Padmini, the symbol of desire, and the somnolent intervention of Kali. Hayavadana narrates his story how he has become a horse-man and all through his life, he has been trying to get rid of his horse's head and requests the Bhagavatha to help him. His origin story points to the play's theme of searching for fulfilment and completion. Hayavadana does not accept his hybrid status, wants to get himself rid of the incomplete feeling and become a complete man through divine intervention, as he is not able to find his "society" in such a status. Karnad builds on the Bhagavatha's earlier remark that human beings never understand the divine completeness in hybrid beings, meaning that they are sacred beings. The Bhagavatha now, advice Hayavadana to offer prayer to the Goddess Kali at Mount Chitrakoot, where once thousands of pilgrims used to throng. But, now people have stopped going there since they have discovered that she granted anything anyone asked. She receives no pujas, no worship, no bells ringing, and exists in a sleepy stage. She has lost the reputation of being a sacred persona.

Apart from Lord Ganesha's image occupying a sacred place on the stage, Kali's temple, the real holy precinct, has to be allowed to make meaningful the theme of transposed heads of the main plot of the play. Kali's temple becomes one of the significant devices, in which the various plot lines of the play intersect and eventually become tied together, as Padmini, Devadatta, and Kapila also go to Kali's temple. The Bhagavatha's comment that pilgrims stopped worshipping her because of her random grants, also foregrounds the profaneness in conducting one's prayer. Karnad seems to hint that simply asking gods does not necessarily sanction completeness in one's identity, as is shown with all the characters who visit Kali's temple. Karnad has deliberately created a not-so-benign, drowsy character Kali, who is no more a deity in the saucer and is deprived of her protocol. She stands at the borderline between sacer and profanes, and in a hurry to pronounce, "so be it". The remnants of her divinity seem to be alive only in some of her words. Words hold high power, and they are the potential receptacles of the sacred. Karnad, perhaps, wishes to present his Kali as a hybrid being, less divine and more human, a fusion of profane and holy, the former exercising its power in her somnolent utterances. In such a moment, poor Hayavadana surrenders and before asking his boon, Kali, disturbed in her sleep, says "so be it", and Hayavadana now becomes a complete horse. 
But, still, he is incomplete because his human voice continues to be with him. The horse-society, too, will not accept him. Again, he has no identity. However, the horseman's search for completeness ends with his becoming a complete horse when Padmini's autistic child begins to laugh at seeing this odd creature that reciprocally makes Hayavadana gain his natural neighing. This mutual life-giving and rejuvenation between the half-human and the human achieves sacredness in the profane locale. Karnad seems to suggest that everyone should accept what is naturally given to them, which would make them complete. In a way, Kali maintains her sacredness by blessing Hayavadana to be a perfect horse.

Ironically, Kali's benevolence towards Padmini when she is quite awake results in total catastrophe but helps to build up the main plot of the play. The story is about Devadatta, a man of intellect and Kapila, a man of muscles. They are two close friends. Devadatta falls in love with Padmini and marries her. Incidentally, Kapila also falls in love with her. Padmini gets attracted to him. Devadatta, suspecting his wife's loyalties, goes to the temple of Goddess Kali and beheads himself. Kapila finds the body and rightfully feels that he would be accused of having killed his dearest friend, since he has coveted his wife, and so, in turn, beheads himself. These tragic events happen in the profane of Kali temple, the goddess herself being the witness from her sanctum. Padmini finds the truncated bodies of the two men in her life she is inconsolable. Afraid of the scandal that is bound to follow, she too prepares to kill herself. Now the goddess Kali takes pity and comes to her aid. There begins the calamity when the benign blessing turns into a real curse, the sacred becoming profane. Kali tells Padmini that she needs only to rejoin the heads to the bodies, and the goddess will bring them back to life. Padmini follows the instructions; the men come back to life- except that in her confusion, she has mixed up the heads. And thereby hangs a disastrous tale showing man's morale in the lowest web with anger, pride, arrogance and disappointment that enfold their psyches. Even the transposition of heads and divine intervention will not liberate the protagonists from the psychological stress imposed by nature. Such a predicament provides Karnad with an opportunity to explore the identity-crisis of the modern man, and also enquire into the age-old question of the sacred and the profane. He employs the mythological tale of the transposed heads from Vetalapanchavimsati in Kathasaritsagara, and the mythic references of Lord Ganesha, Hayagriva and Kali, the last one has a special role in the play, who is neither sacred nor profane. Kali, in general, evokes a terrifying picture in mind, ready to ward off the evil intrusions. But, in the play, she seems to be a social figure, her dozy presence unwittingly instigates knotty problems in these three pitiful human lives.

Emile Durkheim, the French Sociologist, in his influential work, The Elementary Forms of Religious Life (1912), explains the paired concepts, sacred and profane. He argues that Religion could neither be defined in terms of the "supernatural," nor be reduced to ideas of "divinity" or even "spiritual beings." He formulates a radical proposition: "Whether simple or complex, all known religious beliefs display a common feature: They presuppose a classification of the real or ideal things that men conceive of into two classes - two opposite genera - that are widely designated by two distinct terms, which the words profane and sacred translate fairly well. The division of the world into two domains, one containing all that is sacred and the other all this is profane - such is the distinctive trait of religious thought" (34). This division is a necessary precondition to religious beliefs, and in fact, its very foundation. Rudolf Otto, an eminent German theologian and philosopher, in his most famous work, The Idea of the Holy (1923), writes that while the concept of "the holy" is often used to convey moral perfection, it contains another distinct element, beyond the ethical sphere, for which he has coined the term numinous, which has three components, mysterium tremendum et fascinans. As mysterium, the numinous is "wholly other"-entirely different from anything a person experiences in ordinary life and evokes a reaction of silence. It is also a mysterium tremendum, provoking terror because it presents itself as overwhelming power. Finally, the numinous presents itself as fascinans, as merciful and gracious. Kali of Hayavadana does not at all fit into this explication.

For Otto, the "holy" is grounded in individual feeling, an apprehension of something outside the individual and infinitely more significant. Durkheim, 
however, does not deny the importance of such an experience but asserts that it is derived from the idea of the sacred rather than signifying its essence. To him, the concept of "sacred" is above all intrinsically social, the product of the social classification of all facts in the opposing categories of sacred and profane, and so is unthinkable except in terms of the profane. The content of the type holy is intrinsically fluid: anything might be classified as sacred. What matters is the social act of separation from the profane. The Kali figure in Hayavadana is the best illustration. She performs a semi-divine action in her tired state, turning Hayavadana into his horsehood and thus makes him complete. On the other hand, she just remains a spectator, objectively watching Padmini's confusing job of transposing the heads. Hayavadana is a unique play as it encompasses all three spheres of existence - divine, human and animal and all the aspects of life and experience in terms of the Sacred and the Profane.

\section{References}

Durkheim Emile. The Elementary Forms of Religious Life, translated by Karen Fields, Free Press, New York, 1995.

Otto, Rudolf. The Idea of the Holy, translated by John W. Harvey, Oxford University Press, 1923.

Roy, Arundhati. "Transposing Realities." The Hindu Magazine, 4 April 2002, www.thehindu.com/ todays-paper/tp-features/tp-sundaymagazine/ transposing-realities/article28516157.ece.

Tripathi, Vanashree. "Hayavadana: Towards Forging an Indian Theatre." Three Plays of Girish Karnad: A Study in Poetics and Culture, Prestige Books, New Delhi, 2004.

\section{Author Details}

Dr.R.Kalidasan, Associate Professor of English (Retd.), The American College, Madurai, Tamil Nadu, India.

Email ID: rknikkhil@yahoo.com.

Dr.R.K.Jaishree Karthiga, Assistant Professor of English, Thiagarajar College of Engineering, Madurai,

Tamil Nadu, India. 